\title{
HUBUNGAN DUKUNGAN SOSIAL TERHADAP PENGOBATAN KANKER PAYUDARA DI YAYASAN KANKER WISNUWARDHANA
}

\author{
RELATIONSHIP OF SOCIAL SUPPORT TO BREAST CANCER'S TREATMENT
}

\author{
Kevin Patar Aruan, Muhammad Atoillah Isfandiari
}

Departemen Epidemiologi, Fakultas Kesehatan Masyarakat, Universitas Airlangga

Kampus C Mulyorejo, Surabaya

e-mail: kevinpatar@gmail.com

\begin{abstract}
In the city of Surabaya, the number of patients with breast cancer is found and treated in 2014 was amounted to 709 cases. Family social support is regarded as one of the drivers of the patient for treatment. This study aimed to quantify the proportion of delay in treatment of breast cancer based on family and social support and analyzing the relationship of social support by the family against in the treatment of breast cancer cases in Yayasan Kanker Wisnuwardhana Surabaya. The study was conducted using cross sectional design using a quantitative approach. The interview was conducted on 40 patients with breast cancer. Samples were selected by simple random sampling. The results of comparison of proportions delay breast cancer treatment according to the status of family social support is 7.5: 3.6. Testing single relationship between social support by the family to delay treatment shows that there was a significant relationship between social support with treatment of breast cancer $(p<0.05)$. The conclusions are the proportion of delay in treatment more on the respondents were less lack support and there is a relationship between social support to the treatment of breast cancer cases in Yayasan Kanker Wisnuwardhana Surabaya.
\end{abstract}

Keywords: breast cancer, delay treatment, social support.

Abstrak: Di Kota Surabaya, jumlah penderita kanker payudara yang ditemukan dan diobati pada tahun 2014 ialah sebesar 709 kasus. Dukungan sosial keluarga dianggap sebagai salah satu pendorong penderita untuk berobat. Penelitian ini bertujuan untuk menghitung proporsi keterlambatan berobat kanker payudara berdasar dukungan sosial keluarga dan menganalisis hubungan dukungan social keluarga terhadap pengobatan kasus kanker payudara di Yayasan Kanker Wisnuwardhana Surabaya. Penelitian menggunakan rancangan cross sectional dengan pendekatan kuantitatif. Wawancara dilaksanakan pada 40 penderita kanker payudara. Sampel ditarik dari populasi dengan cara simple random sampling. Hasil perbandingan proporsi keterlambatan pengobatan kanker payudara menurut status dukungan sosial keluarga ialah 7,5:3,6. Pengujian hubungan tunggal antara dukungan sosial oleh keluarga terhadap pengobatan menunjukkan bahwa ada hubungan bermakna antara dukungan sosial keluarga dengan pengobatan kanker payudara $(\mathrm{p}<0,05)$. Kesimpulannya adalah proporsi keterlambatan berobat terbanyak pada responden yang kurang mendapat dukungan sosial, ada hubungan antara dukungan sosial terhadap pengobatan kasus kanker payudara di Yayasan Kanker Wisnuwardhana Surabaya.

Kata kunci: dukungan sosial, kanker payudara, keterlambatan pengobatan.

\section{PENDAHULUAN}

Data Riset Kesehatan Dasar Indonesia (2013) menggambarkan bahwa sebanyak $35 \%$ kejadian penyakit yang dilaporkan ialah penyakit menular yang berasal dari agen biologis, sedangkan sisanya $65 \%$ ialah penyakit yang tidak menular. Pergeseran ini menunjukkan bahwa penyakit yang ada bukan berasal dari sebuah agen biologis, namun disebabkan oleh gaya hidup masyarakat masa kini. Penyakit kanker merupakan salah satu penyakit yang tidak menular, namun bersifat kronis dalam perkembangan etiologi penyakitnya

Kanker menurut Wahyuni (2013) ialah suatu penyakit pada DNA pembentukan kromosom yang terdapat pada inti sel. Penyakit kanker terlihat seperti adanya daging atau substansi yang tumbuh secara abnormal di dalam tubuh kita dan menyebabkan terjadinya luka yang sangat hebat dan mengeluarkan nanah. Sel kanker memiliki bentuk dan warna yang beraneka macam, hal ini disebabkan oleh kadar asam nukleat dalam inti sangat tinggi. Sel ini tidak 
tersebar di daerah sekitarnya. Inti relatif lebih besar terhadap sitoplasma dengan rasio hampir mendekati 1 rasio nukleoar. Insidens mitosa naik, serta susunan sel bersifat tidak teratur (Sukardja, 1996).

Sifat sel kanker adalah tumbuh secara berkelanjutan, lebih cepat, lebih tidak berbatas, mendesak serta merusak sel-sel di sekitarnya, dapat bergerak amoeboid sehingga dapat mengadakan invasi jaringan sekitarnya dan metastase yang bersifat regional maupun jauh, tidak mengenal koordinasi dan batas-batas kewajaran. Sel kanker dapat menyusup ke dalam sel normal. Sel kanker tidak akan berhenti apabila terkena kontak dengan sel di sekitarnya. Sel kanker tetap bertumbuh meskipun di tempat yang tidak semestinya sehingga menimbulkan anak sebar atau metastase. Sel kanker tidak mengenal batas kepadatan sehingga sel tetap terus bertumbuh (Sukardja, 1996).

Kasus kanker banyak ditemukan di dunia ialah kanker payudara. Kanker Payudara ialah malignant tumor yang berasal dari payudara (American Cancer Society, 2008). Kanker payudara ialah tumor pada payudara yang menginvasi daerah sekitar payudara dan menyebar keseluruh tubuh (American Cancer Society, 2014). Kanker payudara memiliki berbagai macam faktor risiko. Berikut merupakan penjelasan faktor risiko tersebut. Diet yang salah sehingga menyebabkan kegemukan setelah menopause. Konsumsi serat kurang dari $1 / 2 \mathrm{~kg}$ per hari. Seringnya mengkonsumsi makanan cepat saji. Konsumsi alkohol berlebihan. Wanita yang mendapat haid pertama di bawah umur 12 tahun. Usia melahirkan anak pertama diatas 35 tahun. Wanita yang mengalami menopause diatas usia 50 tahun. Wanita yang menggunakan kontrasepsi oral diatas 7 tahun. Tidak adanya keturunan atau kemandulan. Wanita yang tidak menikah. Riwayat keluarga menderita tumor atau kanker payudara. Mempunyai riwayat terpapar radiasi (DEPKES RI, 2009).

Prediksi American Cancer Society pada tahun 2030, kasus kanker akan meningkat menjadi 21.400 .000 jiwa di dunia dan 13.200.000 jiwa di dunia akan meninggal karena penyakit kanker (American Cancer
Society, 2008). Menurut American Cancer Society pada tahun 2012 jumlah kasus baru kanker payudara di dunia adalah 1.700 .000 kasus, kemudian sebanyak 53\% dari kasus kanker payudara di dunia berada di negara yang sedang berkembang. Sebanyak 59\% dari penderita kanker payudara di dunia berada di benua Asia, sebanyak 39\% merupakan kasus baru, kemudian sebanyak $44 \%$ penderita mengalami kematian, dan hanya sebesar $37 \%$ penderita yang dapat bertahan selama 5 tahun (American Cancer Society, 2012).

Di Indonesia, hasil Riskedas 2013 menunjukkan bahwa penyakit kanker mendapat urutan ke-5 sebagai penyakit yang memiliki prevalensi terbanyak diantara 10 penyakit lainnya. Sesuai dengan hal ini, menurut profil kesehatan Jawa Timur pada tahun 2012 penyakit kanker yang memiliki angka kejadian tinggi ialah kanker payudara. Kanker Payudara mendapat peringkat ke 3 pada 10 penyakit terbanyak yang mendapatkan perawatan inap di RS pemerintah kelas A tahun 2012 di Provinsi Jawa Timur. Di Kota Surabaya tahun 2014, jumlah kasus kanker payudara yang ditemukan dan diobati pada tahun 2014 ialah sebesar 709 kasus dengan proporsi sebesar 35,86\%.

Menurut Karnadihardja (1987), secara sederhana stadium kanker dapat dikelompokkan menjadi 2, yaitu: stadium dini (stadium I dan II) dan stadium lanjut (stadium III dan IV). Apabila stadium kanker ditinjau dari kemungkinan kesembuhan, digolongkan sebagai berikut. Stadium dini (early stage) ialah suatu tingkat yang menunjukkan kanker belum lama diketahui pertumbuhannya masih kecil, letaknya masih lokal terbatas pada organ tempat asal tumbuh serta belum menyebab kerusakan organ sekitar. Stadium lanjut (advanced stage) ialah suatu tingkat kanker yang sudah menimbulkan kerusakan yang cukup besar pada organ yang ditumbuhi serta telah mengadakan penyebaran regional dan infiltrasi ke jaringan lainnya sehingga menyebabkan kemungkinan kesembuhan kecil. Stadium sangat lanjut (for advanced stage) adalah tingkat kanker yang menunjukkan bahwa kanker telah lama ada serta membesar, keadaannya sama seperti 
stadium lanjut, disertai metastase luas diseluruh tubuh dan memiliki kemungkinan sembuh sangat keci (Sukardja, 2010).

Penanganan kanker pada umumnya dilakukan terapi sebagai berikut. Operasi dengan membuang tumor dengan tujuan memperbaiki komplikasi, dan merekronstuksi defek yang ada melalui pembedahan. Radiotheraphy untuk menghancurkan kanker dengan sinar ionisasi. Chemoteraphy untuk membunuh sel-sel kanker dengan obat anti kanker yang disebut sitostatika. Hormonteraphy untuk mengubah lingkungan hidup kanker sehingga pertumbuhannya terganggu dan akhirnya sel kanker mati sendiri. Immunoteraphy untuk memperkuat daya tahan tubuh dan memperbesar kemampuan tubuh menghancurkan sel kanker. Elektrokoagulasi dengan membakar selsel kanker dengan alat listrik electrocauter. Lasersurgery dilakukan dengan membakar sel-sel kanker menggunakan sinar laser seperti Nd-laser dan YAG-laser. Cyrosurgery dilakukan dengan membekukan sel-sel kanker sampai mati dengan menggunakan karbondioksida. Chemosurgery dilakukan dengan membunuh sel-sel kanker dengan bahan kimia. Terapi kombinasi dilakukan dengan cara mengkombinasikan antara cara-cara terapi yang telah disebutkan diatas (Sukardja, 2010).

Keterlambatan pengobatan adalah penderita kanker payudara datang untuk mendapat pengobatan dalam stadium lanjut atau sudah parah sehingga tindakan tidak dapat dilakukan (Tiolena, 2009). Rastad dkk. (2012) menyatakan bahwa keterlambatan pengobatan disebabkan oleh beberapa faktor. Faktor-faktor tersebut dijelaskan sebagai berikut. Defisiensi informasi yang terjadi karena penderita tidak merasakan adanya gejala rasa sakit, walau ada keanehan pada payudaranya. Keluarga penderita merasa tidak adanya riwayat keluarga terkena kanker payudara sehingga menyebabkan ketidaktahuan keluarga mengenai apa yang dihadapi keluarganya. Kesalahan diagnosis yang dilakukan oleh dokter, karena penderita kanker payudara memeriksakan keluhannya pada dokter bukan spesialis onkologi. Penderita ketakutan apabila didiagnosis kanker payudara, sehingga mereka merasa lebih aman karena tidak tahu bahwa dirinya terdiagnosis kanker. Pasien tidak melihat bahwa mereka berisiko terkena kanker payudara. Faktor keluarga penderita dan komitmen akan pekerjaan pasien, karena pasien takut meninggalkan tanggung jawab di dalam keluarga serta takut terganggu pekerjaannya apabila mengikuti pengobatan kanker payudara.

Penundaan pengobatan bisa terjadi oleh karena faktor-faktor yang berasal dari dalam individu. Faktor internal pasien yang menghambat penderita untuk berobat adalah sebagai berikut. Pada stadium dini penderita merasa sehat sehingga penyakitnya dibiarkan saja sampai beberapa lama, bulanan, atau tahunan sampai penyakitnya tidak tertahan. Penderita kurang memperhatikan diri sendiri, sehingga penderita baru menyadari dan mengetahui adanya tumor di dalam tubuhnya sesudah tumor itu besar atau sesudah timbul keluhan. Penderita tidak memahami atau kurang menyadari akan bahaya kanker. Adanya rasa takut karena diketahui bahwa penyakitnya. Penderita merasa takut untuk pergi ke dokter. Penderita memiliki ketakutan untuk dioperasi. Penderita merasa ketakutan penyakitnya cepat menyebar. Penderita merasa takut terhadap penyakitnya. Penderita tidak punya biaya. Keluarga penderita tidak mengijinkan ke dokter. Rumah penderita jauh dari dokter atau pelayanan kesehatan (Sukardja, 1996).

Perilaku perubahan kesehatan pada individu sendiri dapat ditentukan beberapa faktor. Faktor-faktor tersebut menurut Lawrence Green diidentifikasian menjadi 3 faktor. Faktor-faktor tersebut adalah yaitu faktor predisposisi (predisposing factors), faktor pendukung (enabling factors), dan faktor pendorong (reinforcing factors) (Notoadmojo, 2007). Faktor predisposisi ialah faktor pendorong berupa pengetahuan, sikap, keyakinan/kepercayaan, dan nilai yang dianut oleh seorang individu. Faktor pendukung ialah faktor yang diwujudkan melalui ketersediaan pelayanan atau fasilitas untuk menangani permasalahan kesehatan. Faktor pendorong adalah faktor yang terwujud dalam bentuk dorongan dari kelompok refrensi tertentu disekitar individu yang berpengaruh pada referensi perilaku masyarakat (Notoadmojo, 2007). 
Dukungan sosial dalam keluarga menurut House ialah sebagai berikut. Dukungan emosional, dukungan ini berupa ungkapan empati, kepedulian dan perhatian terhadap keluarga yang bersangkutan. Dukungan penghargaan, dukungan ini berupa ungkapan hormat positif untuk seseorang. Dukungan informatif, dukungan ini berupa nasehat, petunjuk dan berupa saran-saran kepada yang berangkutan. Dukungan instrumental, dukungan ini berupa bantuan langsung yang diberikan seperti halnya bantuan materi atau pertolongan langsung (Smet, 1994). Dukungan sosial sangatlah diperlukan bagi penderita kanker payudara saat penderita menjalani pengobatan kemoterapi (Saragih, 2010).

Menurut Mutmainah dkk. (2013), melalui dukungan keluarga yang baik dapat menjadikan seorang individu menjadi lebih mandiri dan yakin akan kemampuannya sendiri. Melalui dukungan ini dapat meningkatkan motivasi dalam diri seseorang. Dukungan keluarga merupakan aspek yang sangat penting dan sangat diperlukan dalam menentukan cepat atau lambatnya proses kesembuhan yang dialami pasien yang bersangkutan.

Tujuan yang hendak dicapai pada penelitian ini dijelaskan sebagai berikut. Mengidentifikasi distribusi karakteristik penderita kanker payudara. Menghitung proporsi penderita kanker payudara yang terlambat berobat menurut status dukungan sosial keluarga. Menganalisis hubungan dukungan sosial keluarga terhadap pengobatan kanker payudara di Yayasan Kanker Wisnuwardhana Surabaya.

\section{METODE PENELITIAN}

Desain penelitian yang digunakan ialah penelitian analitik dengan pendekatan cross sectional. Sasaran penelitian pada penelitian ini adalah penderita kanker payudara yang terhimpun di Yayasan Kanker Wisnuwardhana, yang dipilih menggunakan teknik simple random sampling melalui data rekam medik (data pemeriksaan USG) pasien yang pernah berkunjung dan data penderita kanker payudara yang pernah berkonsultasi di Yayasan Kanker
Wisnuwardhana. Sampel pada penelitian ini sejumlah 40 penderita kanker payudara yang ada di yayasan ini. Pengambilan data dilakukan pada bulan Mei 2016 sampai dengan bulan Juni 2016. Pengambilan data dilakukan menggunakan kuesioner. Kuesioner tersebut berisi pertanyaan mengenai karakteristik responden, stadium penderita berobat pertama kali, kemudian kuesioner pengukuran dukungan sosial keluarga sebanyak 15 item pertanyaan yang mewakili 4 bentuk dukungan sosial.

Teknik analisis yang digunakan pada penelitian ini adalah teknik univariat dan teknik analisis bivariat. Analisis univariat merupakan analisis yang akan digunakan untuk mendeskripsikan data dengan menggambarkan distribusi frekuensi dan proporsi data. Analisis bivariat digunakan untuk menganalisis dua variabel untuk diketahui korelasinya. Analisis ini menggunakan uji Chi-square dengan tingkat kemaknaan sebesar 0,05 .

\section{HASIL PENELITIAN}

Pada tabel 1 dapat diketahui bahwa, karakteristik usia penderita kanker payudara di Yayasan Kanker Wisnuwardhana Surabaya menunjukkan bahwa sebagian besar berada pada rentang usia masa tua. Pada usia antara 41-65 tahun. Jumlah frekuensinya adalah sebesar 34 penderita dengan persentase sebesar $85 \%$ dari total responden.

Pada tabel 1 dapat diketahui bahwa, karaktersitik status pekerjaan penderita kanker payudara di Yayasan Kanker Wisnuwardhana Surabaya menunjukkan bahwa sebagian besar memiliki status pekerjaan. Hasil ini berarti bahwa mayoritas responden adalah pekerja. Jumlah frekuensinya adalah sebesar 30 orang dengan persentase sebanyak $75 \%$ dari total responden.

Pada tabel 1 dapat diketahui bahwa, karakteristik tingkat pendidikan responden sebagian besar menunjukkan penderita kanker payudara di Yayasan Kanker Wisnuwardhana Surabaya menunjukkan bahwa sebagian besar responden memiliki tingkat pendidikan pada jenjang pendidikan tinggi. Hasil ini berarti bahwa responden 
Tabel 1. Karakteristik Responden Kanker Payudara Di Yayasan Kanker Wisnuwardhana Surabaya

\begin{tabular}{llcc}
\hline & Variabel & Frekuensi & Persentase \\
\hline Usia & $\begin{array}{l}\text { Dewasa } \\
(18-40 \text { tahun })\end{array}$ & 6 & $15 \%$ \\
\cline { 2 - 4 } & $\begin{array}{l}\text { Masa Tua } \\
(41-65 \text { tahun })\end{array}$ & 34 & $85 \%$ \\
\hline Status Pekerjaan & Bekerja & 30 & $75,0 \%$ \\
\cline { 2 - 4 } Tidak Bekerja & 10 & $25,0 \%$ \\
\hline Tingkat Pendidikan & $\begin{array}{l}\text { Pendidikan Menengah } \\
\text { (SMP-SMA atau SMK) }\end{array}$ & 9 & $22,5 \%$ \\
\cline { 2 - 4 } & $\begin{array}{l}\text { Pendidikan Tinggi } \\
\text { (Perguruan Tinggi) }\end{array}$ & 31 & $77,5 \%$ \\
\hline Ketepatan Berobat & $\begin{array}{l}\text { Tepat Berobat } \\
\text { (Stadium 1-2) }\end{array}$ & 21 & $52,5 \%$ \\
\cline { 2 - 4 } & $\begin{array}{l}\text { Terlambat Berobat } \\
\text { (Stadium 3-4) }\end{array}$ & 19 & $47,5 \%$ \\
\hline
\end{tabular}

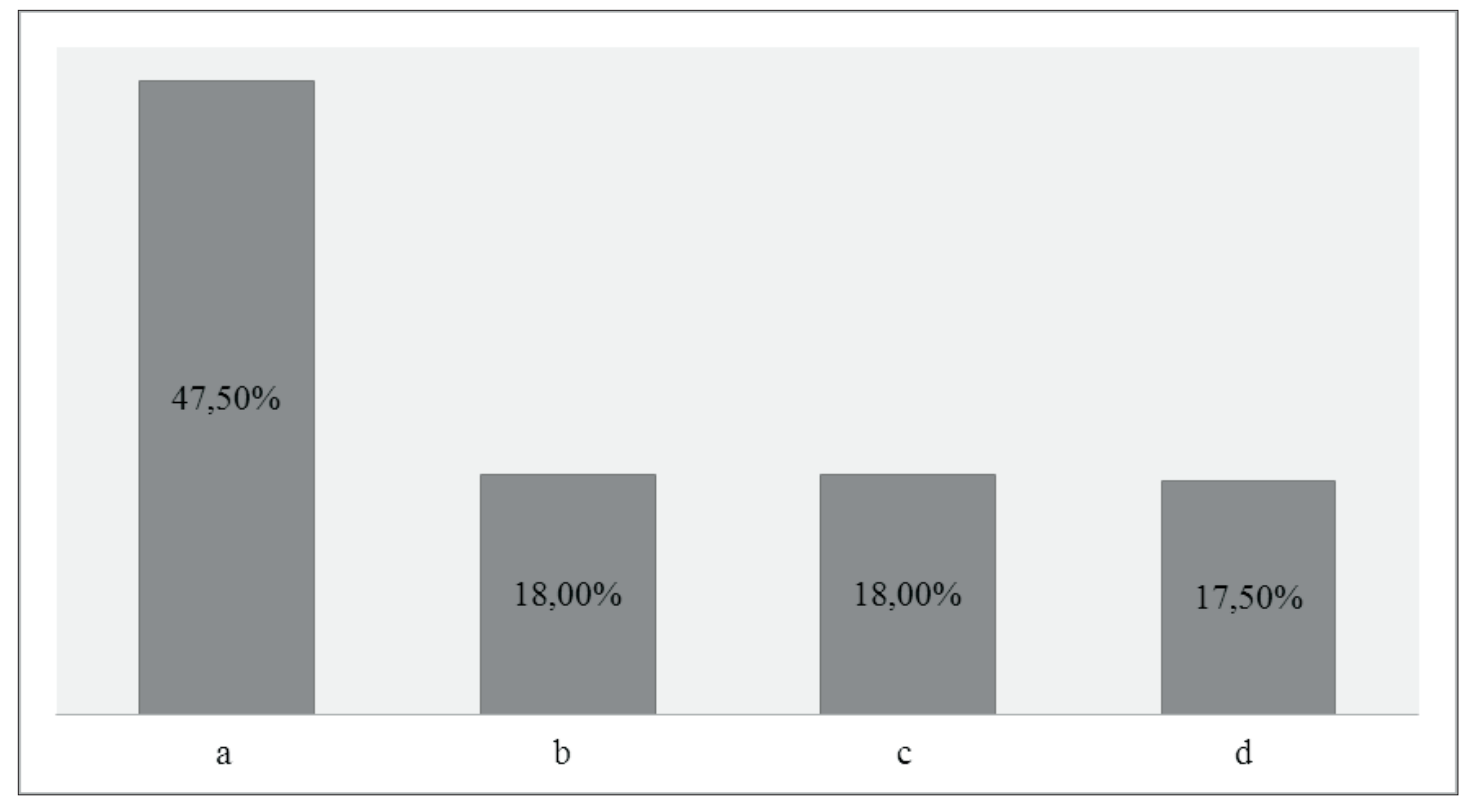

Keterangan:

a: Keluarga menunjukkan 4 bentuk dukungan sosial. c: Keluarga menunjukkan 2 bentuk dukungan sosial.

b: Keluarga menunjukkan 3 bentuk dukungan sosial. d: Keluarga menunjukkan 1 bentuk dukungan sosial.

Gambar 1. Distribusi Bentuk Dukungan Sosial Keluarga Yang Ditunjukkan Oleh Keluarga Penderita Kanker Payudara di Yayasan Kanker Wisnuwardhana Surabaya

mendapat pendidikan terakhir pada jenjang perguruan tinggi (D3-S1). Dengan jumlah frekuensi sebesar 31 orang dengan persentase sebesar $77,5 \%$ dari seluruh responden.

Pada tabel 1 dapat diketahui bahwa, karakteristik ketepatan berobat penderita kanker payudara di Yayasan Kanker
Wisnuwardhana Surabaya pada penelitian ini menunjukkan bahwa sebagian besar responden berobat pada katagori tepat berobat. Penderita pada penelitian ini berobat pada stadium I-II. Jumlah frekuensinya adalah sebesar 21 penderita dengan persentase sebesar $52,5 \%$ dari total responden pada penelitian ini. 
Berdasarkan hasil observasi pada penelitian ini, hasil penelitian karakteristik responden ini bisa didukung oleh letak geografis dari Yayasan Kanker Wisnuwardhana, serta jam operasional dari klinik yayasan ini. Yayasan ini beralamat di Jalan Kayoon 16-18 Surabaya yang terletak tepat di jantung kota Surabaya. Karena letaknya yang berada di tengah kota, maka yayasan ini terletak berdekatan dengan berbagai perkantoran di Kota Surabaya. Jam operasional di yayasan ini dimulai pada pukul 08.00 sampai 13.00 dan dilanjutkan kembali pada pukul 18.00 sampai 19.30 . Sehingga memungkinkan para pekerja serta berbagai kalangan masyarakat untuk mendapatkan pelayanan pemeriksaan kesehatan yang dialami pada payudaranya. Hasil penelitian juga menunjukkan bahwa mayoritas penderita mendapat pengobatan pada katagori tepat berobat. Hasil ini didukung dengan temuan dilapangan yang menunjukkan bahwa mayoritas penderita yang terdata di yayasan ini adalah mereka yang akan melakukan deteksi dini. Melalui hasil tersebut memungkinkan penanganan pengobatan sedini mungkin pada penderita sebelum terjadi keparahan.

Dukungan sosial yang ideal ialah dukungan yang diterima secara baik oleh individu yang meliputi 4 macam bentuk dukungan sosial. Bentuk-bentuk dukungan tersebut ialah dukungan emosional, dukungan penghargaan, dukungan informatif, dan dukungan instrumental. Dukungan emosional ialah dukungan dalam bentuk empati yang diberikan oleh keluarga. Dukungan penghargaan adalah dukungan yang diberikan dalam bentuk pengungkapan hormat positif yang diberikan oleh keluarga. dukungan informatif ialah dukungan yang diberikan oleh keluarga dalam bentuk nasehat dan petuah bagi seorang individu. Dukungan instrumental adalah dukungan yang diberikan dalam bentuk bantuan langsung.

Gambar 1 menunjukkan bahwa beberapa keluarga penderita kanker payudara di Yayasan Kanker Wisnuwardhana Surabaya sudah memberikan dukungan sosialnya secara ideal pada responden dengan memberikan 4 bentuk dukungan sosial pada responden. Keluarga sudah memberikan dukungan emosional, dukungan penghargaan, dukungan informatif, dan dukungan instrumental. Jumlah persentasenya sebesar $47 \%$ dari total seluruh responden. Sedangkan banyak keluarga penderita kanker payudara di yayasan ini yang belum memberikan dukungan sosialnya secara utuh pada responden. Gambar tersebut juga menunjukkan bahwa

sebagian kecil dari keluarga responden hanya menunjukkan dukungan sosialnya pada responden dalam bentuk salah satu dukungan sosial saja dengan presentase sebesar $17 \%$ dari total seluruh responden penderita kanker payudaradi Yayasan KankerWisnuwardhana. Pada hasil penelitian ini akan ditunjukkan hasil dari pengukuran dukungan sosial pada keluarga penderita kanker payudara di Yayasan Kanker Wisnuwardhana Surabaya yang dihubungkan dengan status pengobatan pertama kali penderita kanker payudara. Melalui tabel ini juga dapat diketahui nilai $p$-value melalui uji chi square serta dapat diketahui nilai prevalens rasio guna mengetahuipeluang atau risiko keterlambatan berobat akibat penundaan penderita kanker payudara di Yayasan Kanker Wisnuwardhana untuk mendapatkan pengobatan pertama kali dengan menggunakan program analisis Epi Info.

Tabel 2. Hubungan Dukungan Sosial Terhadap Pengobatan Kanker Payudara Di Yayasan Kanker Wisnuwardhana Surabaya

\begin{tabular}{lccc}
\hline & Terlambat Berobat & Tepat Berobat & Total \\
\hline Dukungan Sosial Kurang & $9(\mathrm{a})$ & $3(\mathrm{~b})$ & 12 \\
& $(75,0 \%)$ & $(25,0 \%)$ & $(100 \%)$ \\
\hline Dukungan Sosial Baik & $10(\mathrm{c})$ & $18(\mathrm{~d})$ & 28 \\
& $(35,7 \%)$ & $(64,3 \%)$ & $(100 \%)$ \\
\hline \multirow{2}{*}{ Total } & 19 & 21 & 40 \\
& $(47,5 \%)$ & $(52,5 \%)$ & $(100 \%)$ \\
\hline
\end{tabular}


Hasil perhitungan proporsi tersebut: Proporsi penderita kanker payudara di Yayasan Kanker Wisnuwardhana Surabaya dengan dukungan sosial keluarga kurang dan mengalami keterlambatan berobat $=\mathrm{a} /$ $(a+b), 9 /(9+3)=0,75$, yang berarti bahwa sebanyak $75 \%$ penderita kanker payudara di Yayasan Kanker Wisnuwardhana Surabaya yang kurang mendapatkan dukungan sosial keluarga mengalami keterlambatan berobat. Sedangkan, proporsi penderita kanker payudara di Yayasan Kanker Wisnuwardhana Surabaya dengan dukungan sosial keluarga baik dan mengalami keterlambatan berobat $=\mathrm{c} /(\mathrm{c}+\mathrm{d}), 10 /(10+18)=0,36$, yang berarti bahwa sebanyak $36 \%$ penderita kanker payudara di Yayasan Kanker Wisnuwardhana Surabaya yang mendapatkan dukungan sosial keluarga dengan baik mengalami keterlambatan berobat.

Selanjutnya, hasil pada tabel 2 diuji untuk mengetahui hubungan antara dukungan sosial dengan status pengobatan penderita kanker payudara. Hasil uji tersebut menggunakan tingkat kemaknaan sebesar 0,05 atau memiliki nilai $\alpha$ sebesar 0,05. Dari pengujian tersebut didapati bahwa nilai $\mathrm{p}=0,0226$, yang berarti bahwa nilai $p$ kurang dari $\alpha$ sehingga dapat disimpulkan bahwa terdapat hubungan antara dukungan sosial keluarga terhadap pengobatan kanker payudara di Yayasan Kanker Wisnuwardhana Surabaya.

Melalui hasil perhitungan nilai Rasio Prevalensi pada penelitian ini juga menunjukkan nilai Rasio Prevalensi (RP) 2,100 ; dengan 95\%CI $(1,1586<\mathrm{RP}<$ 3,8062 ) nilai ini memiliki arti bahwa penderita kanker payudara di Yayasan Kanker Wisnuwardhana Surabaya yang kurang mendapatkan dukungan sosial keluarga memiliki peluang untuk mengalami keterlambatan mendapatkan pengobatan sebesar 2,1 kali lebih besar dibanding penderita kanker payudara di Yayasan Kanker Wisnuwardhana Surabaya yang mendapatkan dukungan sosial keluarga dengan baik.

\section{PEMBAHASAN}

Hasil penelitian pada karakteristik usia responden penderita kanker payudara menunjukkan bahwa responden penderita kanker payudara di Yayasan Kanker Wisnuwardhana Surabaya terbanyak pada rentang usia masa tua. Hasil penelitian ini sesuai dengan hasil penelitian Sari dkk., (2012) yang mendapati bahwa responden penderita kanker payudara terbanyak pada rentan usia 41-65 tahun. Hasil penelitian ini didukung dengan hasil penelitian yang dilakukan oleh Harianto (2005), yang menunjukkan bahwa insidensi kanker payudara meningkat seiring bertambahnya usia. Namun hasil penelitian ini berbeda dengan yang didapatkan oleh Anggorowati (2012), yang mendapati hasil penelitian bahwa kejadian kanker payudara terjadi pada wanita yang berusia di bawah 42 tahun. Hasil ini didukung dengan observasi di lapangan yang menunjukkan bahwa pemeriksaan deteksi dini payudara di Klinik Yayasan Kanker Wisnuwardhana Surabaya mencakup semua usia, sehingga memungkinkan setiap perempuan pada semua rentang untuk memeriksakan keadaan maupun gejala yang terdapat di payudaranya.

Hasil penelitian karakteristik status pekerjaan responden penderita kanker payudara di Yayasan Kanker Wisnuwardhana Surabaya mendapati hasil bahwa sebagian besar responden penderita kanker payudara pada penelitian ini memiliki status pekerjaan sebagai pekerja. Hasil penelitian ini tidak sesuai dengan hasil penelitian yang dilakukan oleh Hikmanti dan Adriani (2014), yang mendapati bahwa penderita kanker payudara baik yang terlambat berobat maupun tepat berobat terbanyak pada mereka yang berstatus sebagai IRT (ibu rumah tangga) atau tidak bekerja. Hasil penelitian serupa juga didapatkan oleh Tiolena (2009), yang mendapatkan hasil bahwa penderita kanker payudara yang terlambat berobat ialah mereka yang memiliki status pekerjaan sebagai IRT. Perbedaan hasil penelitian pada penderita kanker payudara ini bisa terjadi oleh karena perbedaan metode penelitian dan metode sampling yang digunakan pada kedua penelitian ini. Pada penelitian ini menggunakan metode kuantitatif, sedangkan pada penelitian yang dilakukan oleh Hikmanti dan Adriani serta Tiolena 
menggunakan sampling accidental dan menggunakan metode penelitian kualitatif sehingga menyebabkan terjadinya perbedaan hasil penelitian.

Hasil penelitian karakteristik pendidikan responden penderita kanker payudara di Yayasan Kanker Wisnuwardhana Surabaya menunjukkan bahwa sebagian besar memiliki pendidikan pada jenjang perguruan tinggi. Hasil penelitian ini sesuai dengan hasil penelitian yang didapati oleh Djatmiko dkk. (2013) yang mendapati mayoritas penderita kanker payudara ialah mereka yang mempunyai pendidikan terakhir pada jenjang D3, S1 dan diatas jenjang S1. Kesamaan dari hail penelitian ini bisa terjadi karena jenis dan metode yang digunakan dalam penelitian ini sama. Hasil observasi penelitian di lapangan pada saat proses pengambilan data, menunjukkan bahwa beberapa penderita kanker payudara yang berpartisipasi pada penelitian ini mengatakan bahwa mereka berobat di rumah sakit penanganan kanker yang menjadi tempat dari penelitian yang dilakukan oleh Djatmiko dkk. pada tahun 2013. Maka berdasarkan observasi tersebut dapat terlihat terjadinya kemungkinan kesamaan hasil oleh karena kesamaan tempat destinasi pengobatan lanjutan pada penderita kanker payudara pada penelitian ini dengan penelitian yang dilakukan oleh Djatmiko dkk.

Hasil penelitian karakteristik status pengobatan responden penderita kanker payudara di Yayasan Kanker Wisnuwardhana Surabaya menunjukkan bahwa mayoritas responden penderita kanker payudara pada penelitian ini berobat pada katagori tepat berobat. Hasil penelitian ini tidak sesuai dengan hasil penelitian yang didapati oleh Pratiwi (2011) yang mendapatkan hasil bahwa sebanyak $60-70 \%$ pasien kanker payudara berobat pertama kali pada stadium 3 dan stadium 4. Berdasarkan hasil observasi penelitian di lapangan, sebagian besar penderita yang datang berkunjung ke yayasan ini ialah mereka yang memiliki tujuan untuk melakukan deteksi dini pada payudaranya. Pelayanan yang didapat memiliki tujuan untuk mencegah terjadinya keparahan atau untuk mengetahui penyebab terjadinya gejala pada payudaranya.
Beberapa penderita yang berkonsultasi dengan pihak yayasan mengenai penyakit kanker yang sedang dihadapi supaya mendapat kiat-kiat untuk mempertahankan kondisi psikologis dari penderita dalam menjalani serangkaian pengobatan yang akan dijalani. Pada hasil penelitian yang dilakukan oleh Pratiwi (2011), para penderita kanker payudara yang berpartisipasi pada penelitian tersebut ialah mereka yang akan menjalani pengobatan pertama maupun lanjutan di rumah sakit. Adapun rumah sakit pada penelitian yang dilakukan oleh Pratiwi adalah rumah sakit yang menjadi rujukan guna menangani pengobatan lanjutan bagi penderita kanker payudara yang tentunya sudah mencapai stadium lanjut. Sehingga dapat kita ketahui bahwa perbedaan hasil penelitian ini bisa disebabkan oleh adanya perbedaan tujuan dari penderita untuk mendapatkan pengobatan atau pelayanan yang berkaitan dengan gejala kesehatan yang terjadi pada payudara penderita.

Hasil perbandingan proporsi penderita kanker payudara di Yayasan Kanker Wisnuwardhana Surabaya yang terlambat berobat dengan dukungan sosial keluarga kurang dengan proporsi penderita kanker payudara yang terlambat berobat dengan dukungan sosial keluarga baik ialah sebesar 7,5:3,6. Hasil yang didapatkan pada penelitian ini menunjukkan bahwa sebagian besar penderita kanker payudara di Yayasan Kanker Wisnuwardhana Surabaya yang terlambat berobat terpapar dengan kurang mendapatkan dukungan sosial keluarga. Hasil penelitian ini didukung dengan hasil penelitian yang dilakukan oleh Sari dkk. (2012), yang menunjukkan bahwa penderita kanker payudara yang mempunyai status dukungan keluarga rendah maka akan berisiko serta berpeluang untuk mengalami 9 kali lebih rendah memiliki motivasi dalam menjalani pengobatan, dibanding penderita kanker payudara yang memiliki status dukungan keluarga yang tinggi. Dari hasil tersebut dapat diketahui bahwa dukungan keluarga berbanding lurus mempengaruhi motivasi penderita kanker payudara untuk mendapatkan pengobatan. Hasil pada penelitian ini juga sesuai dengan penelitian pada penderita kanker payudara yang dilakukan oleh Mutmainah dkk. (2013), 
yang mendapati hasil bahwa terdapat hubungan antara dukungan keluarga dengan motivasi untuk sembuh dari penderita kanker payudara sehingga mendorong penderita untuk segera mendapatkan pengobatan.

Hasil gambaran diskripsi dukungan keluarga pada penelitian ini menunjukkan bahwa beberapa penderita kanker payudara sudah mendapatkan dukungan sosial keluarga dengan ideal. Hasil ini berarti bahwa penderita sudah menerima 4 bentuk dukungan sosial di dalam keluarganya, namun sebagian besar belum mendapat belum mendapatkan dukungan sosial keluarga secara penuh. Hasil penelitian ini memiliki makna bahwa sebagian besar responden penderita kanker payudara di Yayasan Kanker Wisnuwardhana Surabaya sebagian besar sudah mendapatkan dukungan untuk menjadi pribadi yang lebih mandiri, serta yakin akan kemampuannya sendiri sehingga dapat meningkatkan motivasi di dalam dirinya. Secara khusus memiliki motivasi dalam menjalani pengobatan penyakit kanker payudara (Mutmainah dkk., 2013).

Hasil ini juga didukung dengan hasil observasi di lapangan, yakni cerita penderita. Penderita bercerita bahwa mereka yang mendapatkan dukungan dari keluarganya akan membuat mereka merasa sangat dihargai, merasa keluarga membutuhkan penderita serta menginginkan penderita untuk selalu bersama keluarga dalam menjalani berbagai aktivitas dan kegiatan di dalam keluarga. Oleh karena itu melalui dukungan tersebut dapat memotivasi penderita untuk berusaha melawan penyakit yang sedang dialami, maka penderita akan termotivasi untuk mendapatkan pengobatan dan merasa dikuatkan dalam menjalani gejala-gejala yang dia rasakan.

Hasil pada penelitian hubungan dukungan sosial terhadap pengobatan kanker payudara di Yayasan Kanker Wisnuwardhana Surabaya menunjukkan hasil bahwa ada hubungan antara dukungan sosial keluarga terhadap keterlambatan pengobatan kanker payudara di Yayasan Kanker Wisnuwardhana Surabaya. Dari hasil penelitian ini juga dapat dilihat nilai
Rasio Prevalensi sebesar 2,100. Hasil ini berarti bahwa penderita kanker payudara di Yayasan Kanker Wisnuwardhana yang kurang mendapatkan dukungan sosial keluarga yang memiliki peluang atau risiko untuk terlambat mendapatkan pengobatan sebesar 2 kali lebih besar dibanding penderita kanker payudara yang memiliki status dukungan sosial keluarga yang baik.

Hasil pada penelitian ini sesuai dengan hasil pada penelitian yang dilakukan oleh Sari dkk. (2012), yang mendapatkan hasil dukungan keluarga berbanding lurus mempengaruhi motivasi penderita untuk berobat. Hasil pada penelitian ini juga sesuai dengan hasil penelitian pada penderita kanker payudara yang dilakukan oleh Mutmainah dkk. (2013), hasil penelitian ini mendapati bahwa terdapat hubungan antara dukungan keluarga dengan motivasi untuk sembuh dari penderita kanker payudara. Hasil observasi peneliti di lapangan menemukan bahwa, sebagian besar penderita yang berobat tepat mengatakan bahwa sudah mendapatkan dukungan penuh dari keluarga yang memotivasi penderita kanker payudara untuk segera sembuh. Oleh karena itu penderita kanker payudara merasa bahwa kesehatan dari dirinya sendiri adalah sebagai sebuah prioritas bagi keluarganya dan merupakan kebutuhan pokok bagi keluarganya. Beberapa penderita juga menceritakan bahwa, melalui dukungan sosial keluarga yang diterima oleh responden penderita kanker payudara memiliki dampak bagi penderita yakni menekan tingkat stress yang dialami pasca dinyatakan terdiagnosis kanker oleh dokter. Namun ketika mendengar motivasi dan melihat usaha maupun keterlibatan keluarga untuk memberikan dukungan bagi penderita untuk segera mendapatkan atau mencari pengobatan. Para penderita ini menjadi semangat kembali untuk segera mendapatkan pengobatan demi kesembuhan penyakit kanker payudara yang sedang dialami. Melalui bentuk kongkrit dukungan inilah yang memotivasi penderita kanker payudara di Yayasan Kanker Wisnuwardhana Surabaya untuk segera mendapat pengobatan tanpa penundaan untuk memperoleh pengobatan sedini mungkin. 


\section{SIMPULAN}

Karateristik penderita kanker payudara di Yayasan Kanker Wisnuwardhana ialah penderita kanker payudara pada rentang usia masa tua yang memiliki status pekerjaan sebagai pekerja, serta berpendidikan pada jenjang perguruan tinggi, dan berobat pada katagori tepat berobat. Proporsi penderita kanker payudara di Yayasan Kanker Wisnuwardhana Surabaya yang terlambat berobat karena kurang mendapatkan dukungan sosial dari keluarga lebih besar dibandingkan proposi penderita kanker payudara yang terlambat berobat namun merasakan dukungan sosial keluarga yang baik. Hasil penelitian ini menunjukkan bahwa terdapat hubungan antara dukungan sosial keluarga terhadap keterlambatan pengobatan kasus kanker payudara di Yayasan Kanker Wisnuwardhana Surabaya. Penderita kanker payudara di Yayasan Kanker Wisnuwardhana Surabaya yang kurang mendapatkan dukungan sosial akan berpeluang untuk terlambat berobat sebesar 2,1 kali lebih besar dibandingkan penderita kanker payudara yang terlambat berobat yang sudah merasakan dukungan sosial dengan baik.

\section{SARAN}

Sebaiknya pihak Yayasan Kanker Wisnuwardhana mengadakan kegiatan pendampingan serta pembinaan keluarga penderita kanker payudara melalui jangkauan relawan dan komunitas peduli penanggulangan kanker berbasis masyarakat. Kegiatan ini terfokus pada edukasi keluarga penderita kanker payudara. Tujuannya adalah untuk memberikan edukasi mengenai keterlibatan keluarga melalui bentuk dukungan sosial pada setiap proses kegiatan pengobatan penderita kanker bagi penderita kanker payudara sendiri.

Sebaiknya peneliti selanjutnya lebih berpartisipasi secara aktif pada pemberian edukasi pada keluarga penderita mengenai dukungan sosial bagi penderita, guna memotivasi penderita untuk sembuh. Kemudian peneliti selanjutnya lebih mengatur waktu dan mematangkan persiapan penelitian dengan tepat. Oleh karena sulitnya mencari responden penderita yang mau terbuka dan bisa diwawancara serta berpartisipasi aktif pada penelitian sehingga tidak mengganggu proses penyusunan laporan penelitian.

Sebaiknya keluarga penderita berpartisipasi aktif bertanya kepada penderita mengenai apa yang dirasakan. Kemudian keluarga juga ikut berperan aktif dalam usaha mencari pengobatan bagi penderita, sehingga menekan angka keterlambatan berobat. Keluarga selalu mendampingi penderita baik pada saat penderita memeriksakan diri pada dokter maupun pada saat penderita memeriksakan gejala yang dihadapi.

\section{DAFTAR PUSTAKA}

American Cancer Society, 2014. Breast Cancer. Atlanta: American Cancer Society.

American Cancer Society, 2014. Cancer Facts And Figure. Atlanta: American Cancer Society.

American Cancer Society, 2012. Global Facts And Figure. 3rd ed. Atlanta.

American Cancer Society, 2008. Global Facts And Figure 2nd Edition. 2nd ed. Atlanta: American Cancer Society.

Anggorowati, L., 2013. Faktor Risiko Kanker Payudara Wanita. Jurnal Kesehatan Masyarakat, VIII(2), pp.121-26.

Badan Penelitian Dan Pengembangan Kesehatan Kementerian Kesehatan RI, 2013. Riset Kesehatan Dasar Tahun 2013. Jakarta: Kementerian Kesehatan Republik Indonesia.

Departemen Kesehatan RI, 2009. Buku Saku Pencegahan Kanker Leher Rahim Dan Kanker Payudara. Jakarta: Departemen Kesehatan RI

Dewi, E.N., 2013. Perilaku Mencari Pengobatan Pada Penderita Kanker Payudara (Studi Kasus Pada Penderita Kanker Payudara Berhasil Sembuh Menjalani Pengobatan Secara Medis). Undergraduate Thesis. Surakarta: Universitas Muhammadyah Universitas Muhammadyah

Djatmiko, A., Octovianus, J., Fortunata, N. \& Andaru, I., 2013. Profil Cancer Delay Pada Kasus Kanker Payudara di RS Onkologi Surabaya. Indonesian Journal Of Cancer, VII, pp.47-52. 
Harianto dkk. 2005. Risiko Penggunaan pil Kontrasepsi kombinasi terhadap Kejadian Kanker Payudara pada reseptor KB di perjan RS. Dr. Cipto Mangunkusumo. Majalah Ilmu Farmasi, 2(1)

Hikmanti, A. \& Adriani, F.H.N., 2014. AnalisisFaktor-FaktorYang Memengaruhi Keterlambatan Pengobatan Pasien Kanker Payudara. Jurnal Universitas Muhammadyah Semarang.

Karnadihardja. 1987. Buku Ajar Ilmu Bedah. Jakarta: Balai Penerbit FK UI.

Komite Nasional Penanggulangan Kanker, 2015. Kanker Payudara. Jakarta: Kementerian Kesehatan RI.

Muhamad, M., Afshari, M. \& Kazilan, F., 2011. Family Support In Cancer Survivorship. Asian Pacific Journal Of Cancer Prevention, XII, pp.1389-97.

Mutmainah, Rahayu, S., Priyogo, N.I. \& Hartanti, R.D., 2013. Hubungan Antara Dukungan Keluarga Terhadap Motivasi Untuk Sembuh Pada Pasien Kanker Yang Menjalani Kemoterapi Di RSUD Kraton Kabupaten Pekalongan. Laporan Penelitian. Pekalongan: STIKES Muhammadiyah Pekajangan Pekalongan

Notoatmodjo, S., 2012. Promosi Kesehatan Dan Perilaku Kesehatan. Jakarta: Rineka Cipta. Pemerintah Provinsi Jawa Timur, 2012. Profil Kesehatan Provinsi Jawa Timur. Surabaya: Pemprov Jatim.

Pratiwi, E.I., 2011. Faktor Yang Mempengaruhi Keterlambatan Penderita Kanker Payudara Dalam Memeriksakan Diri Ke Pelayanan Kesehatan (Studi Dilakukan di Rumah Sakit Umum Daerah Dr. Soetomo Surabaya). Undergraduate
Thesis. Surabaya: Universitas Airlangga.

Sari, D.P., 2014. Gambaran Dukungan Keluarga Pada Pasien Kanker Yang Menjalani Terapi Di RSUD Panembahan Senopati Bantul. Undergraduate Thesis. Yogyakarta: Universitas Muhammadyah Fakultas Kedokteran dan Ilmu Kesehatan.

Sari, M., Devi, Y.I. \& Utami, A., 2012. Hubungan Dukungan KeluargaTerhadap Motivasi Pasien Kanker Payudara Dalam Menjalani Kemoterapi Di Ruang Cendrawasih 1 RSUD Arifin Achmad Provinsi Riau. Jurnal Ners Indonesia, II(2), pp.158-66.

Smet, B., 1994. Psikologi Kesehatan. Jakarta: Grasindo.

Sukardja, I.D.G., 2000. Onkologi Klinik. Surabaya: Airlangga University Press.

Tiolena H, R., 2009. Faktor-Faktor Yang Mempengaruhi Keterlambatan Pengobatan Pada Wanita Penderita Kanker Payudara RSUP H. Adam Malik Medan Tahun 2008.

Undergraduate Thesis. Medan: Universitas Sumatera Utara Fakultas Kesehatan Masyarakat Universitas Sumatera Utara.

Wahyuni, C.U., Martini, S., Isfandiari, M.A. \& Hargono, A., 2013. Epidemiologi Penyakit Tidak Menular. Surabaya: Fakultas Kesehatan Masyarakat Universitas Airlangga.

WHO, 2013. Latest Cancer Statistics Global Cancer Burden Rises To 14.1 Million New Cases In 2012: Marked Increase In Breast Cancer Must Be Addressed. Lyon: IARC WHO. 